Project ID: 54741

\title{
Project Title: Characterization of Contaminant Transport Using Naturally-Occurring U- Series Disequilibria: In-Situ Radionuclide Transport and Preferential Groundwater flows at INEEL (Idaho)
}

\author{
Principal Investigators: Teh-Lung Ku and Shangde Luo \\ Dept. of Earth Sciences \\ University of Southern California \\ Los Angeles, CA 90089-0740 \\ phone: 213-740-5826 \\ email: rku@usc.edu \\ Michael Murrell (Lead-PI) and Robert Roback \\ CST-11, Los Alamos National Laboratory \\ Los Alamos, NM 87545 \\ phone: 505-667-4845 \\ email: mmurrell@lanl.gov \\ Major Collaborators: $\quad$ Robert Smith and Travis McLing \\ Idaho National Engineering and Environmental Laboratory \\ 2251 North Blvd. \\ Idaho Falls, ID 83415-2107
}

\section{Numbers of graduate students/post-doctorates involved:}

1 graduate student; 1 post-doctorate (USC only)

\section{Problems}

The Idaho National Engineering and Environmental Laboratory (INEEL) is a Department of Energy facility that encompasses approximately $2300 \mathrm{~km}^{2}$ in the west-central part of the Eastern Snake River Plain. Since the early 1950s, low-level radioactive and non-radioactive waste was disposed of via injection wells that penetrate to the aquifer. Contaminant plumes extend downgradient from these injection wells and some contaminants can be tracked to near the southern boundary of the site. In addition, there are several surface and shallowly buried waste storage sites that have released contaminants to the environment. Concerns about existing and potential additional contamination of the aquifer have prompted numerous studies to better understand groundwater flow and contaminant migration in the aquifer. This research is directed toward an assessment of rates of the water-rock-radionuclide interactions, the preferential groundwater flow paths, and the transport of radionuclides in fracture-rock systems using a natural analog approach. It falls under one of the five focused topical areas of the ER/EM Collaborative Research Program (Topic 1 of the ER/EM Collaborative Research Solicitation: September 1995).

\section{$\underline{\text { Research objectives }}$}

The goal of the research is to study the migration of nuclear waste contaminants in subsurface fractured systems using naturally occurring uranium- and thorium-series radionuclides as tracers under in-situ physico-chemical and hydrogeologic conditions. We develop a model of contaminant migration in the Snake River Plain Aquifer beneath the INEEL by evaluating the retardation processes involved in the rock/water interaction. The major tasks are to determine: (1) the 
distribution of $\mathrm{U}, \mathrm{Th}, \mathrm{Pa}, \mathrm{Ra}, \mathrm{Rn}, \mathrm{Po}$ and Po isotopes in groundwater as well as in rock minerals and sorbed phases, (2) through modeling the extent of disequilibria the in-situ retardation factors of radionuclides and rock/water interaction time scales, and (3) the water residence time in the aquifer and the preferential flow paths. The study provides an improved characterization of preferential flow and contaminant transport in fractured rocks - information that pertains to risk and performance assessment and remediation action at INEEL and other contaminated DOE sites.

\section{Research Progress at USC}

The project is a collaborated research between the University of Southern California (USC) and the Los Alamos National Laboratory (LANL). Studies performed at USC include the measurement of $\mathrm{U}, \mathrm{Th}, \mathrm{Ra}, \mathrm{Rn}, \mathrm{Pb}$, and Po radionuclides by decay-counting techniques and the modeling of the migration behaviors of these radionuclides.

We have developed an in-situ filtration-enrichment sampling system to obtain groundwater samples sufficiently large to allow measurement of the short- as well as long-lived nuclides of the $\mathrm{U}$ and Th decay chains. It was successfully deployed to collect groundwater samples of $\sim 1000$ liters from 23 wells from INEEL. Isotopes of uranium $\left({ }^{238} \mathrm{U},{ }^{234} \mathrm{U}\right)$, thorium $\left({ }^{232} \mathrm{Th},{ }^{230} \mathrm{Th},{ }^{228} \mathrm{Th}\right.$, $\left.{ }^{234} \mathrm{Th}\right)$, radium $\left({ }^{226} \mathrm{Ra},{ }^{228} \mathrm{Ra},{ }^{224} \mathrm{Ra}\right)$, polonium $\left({ }^{210} \mathrm{Po}\right)$, and lead $\left({ }^{210} \mathrm{~Pb}\right)$ were pre-concentrated in the field by passing 1000 liters of groundwater through two cartridge filtration units (connected in series) containing $\mathrm{MnO}_{2}$-impregnated acrylic fiber adsorbers. Small-volume samples were collected for ${ }^{222} \mathrm{Rn}$ measurements by the radon emanation method using alpha-scintillation counting. Three field sampling trips were completed during the first two years of the project. We have accomplished most of the analyses on the groundwater samples (except for ${ }^{210} \mathrm{~Pb}$ whose activities are determined through ${ }^{210}$ Po ingrowth which requires about one year's time after separation of $\mathrm{Pb}$ from the samples), and have thus far obtained data on a range of wells from the site to allow the following summary of results.

The results show that groundwater activities of Th and Ra isotopes are 2-4 orders lower than those of their $U$ progenitors which average $1.35 \pm 0.40 \mathrm{dpm}{ }^{238} \mathrm{U} / \mathrm{L}$, with ${ }^{234} \mathrm{U} /{ }^{238} \mathrm{U}$ ratios of $\sim 1.6-$ 3.0. ${ }^{222} \mathrm{Rn}$ activities range from 20 to $500 \mathrm{dpm} / \mathrm{L}$. Modeling of the observed disequilibria places the following constraints on the time scale of radionuclide migration and water-rock interaction at INEEL: (1) Time for sorption is minutes for $\mathrm{Ra}$ and Th; time for desorption is days for $\mathrm{Ra}$ and years for Th; time for precipitation is days for Th, years for Ra, and centuries for U. (2) Retardation factors due to sorption average $>10^{6}$ for ${ }^{232} \mathrm{Th}, \sim 10^{4}$ for ${ }^{226} \mathrm{Ra}$, and $\sim 10^{3}$ for ${ }^{238 \mathrm{U}}$. (3) Dissolution rates of rocks are $\sim 70$ to $800 \mathrm{mg} / \mathrm{L} / \mathrm{y}$. (4) Ages of groundwater range from $<10$ to 100 years. Contours of groundwater age, as well as spatial patterns of radionuclide disequilibria, delineate two north-south preferential flow pathways and two stagnated locales. Relatively high rates of dissolution, precipitation, and $\alpha$-recoil of ${ }^{222} \mathrm{Rn}$ occur near the groundwater recharging sites and in the major flow pathways. Decay of the sorbed parent radionuclides (e.g., ${ }^{226} \mathrm{Ra}$ and $\left.{ }^{228} \mathrm{Ra}\right)$ on micro-fracture surfaces constitutes an important source of their daughter $\left({ }^{222} \mathrm{Rn}\right.$ and ${ }^{228} \mathrm{Th}$ ) activities in groundwater.

This study, by providing for the first time a comprehensive and quantitative assessment of the in-situ migration rates of radionuclides in the groundwater of a DOE site, shows that the naturallyoccurring decay-series isotopes in groundwater are uniquely suited for study of site-specific, longterm transport of nuclear wastes in the groundwater. The study reveals the importance of dissolution and precipitation in controlling the transport of radionuclides in groundwater which are difficult to ascertain through lab experiments. Recognizing the role of a sorbed pool of radionuclides in aquifer rocks by this study cautions us in the use of batch experiments to determine distribution coefficients of radionuclides, as many of the surface sorption sites on rocks are formed in nature over geological time scales. 


\section{Information Access (copies of the following publications are available from USC)}

- Ku T. L., Luo S., Leslie B. W., and Hammond D. E. (1998) Radiochimica Acta, 80, 219-223. • Luo S., Ku T. L., Roback R., Murrell M. T., and McLing T. (2000)Geochim. Cosmochim. Acta, 64, 867-881. • Luo S., Ku T. L., Roback R., Murrell M. T., and McLing T. (in press) in: Scientific Basis for Nuclear Waste Management XXIII, proceedings vol. 608 of the Materials Research Society Symposium Proceedings Series. • E-prints: http://emsp.em.doe.gov 